\title{
Methodological Aspects and Methods of Transfer Pricing in Ukrainian Banking Institutions
}

\author{
TARAS SAVChENKo**
}

\begin{abstract}
This article examines the methodological aspects and methods of transfer pricing in Ukrainian banking institutions.

It explores the approaches used to define the functions of transfer pricing from the perspective of pricing theory and enterprise economics theory. It reviews the international and national experiences in the legal regulation of this type of pricing. It identifies the methodological preconditions for the use of transfer prices in banking institutions.

The paper examines graphic models of transfer pricing. Based on calculations from the Hirschmann-Herfindale Index and the Lerner Index, it determines the level of competition on the banking market in Ukraine as of 1 January 2006. Conclusions are made concerning the practical utility of a theoretical model of transfer pricing, based on a study of the nature of an intermediate banking product and the degree of competitiveness of the banking market in Ukraine. The paper reviews the transfer pricing practices in Ukrainian banking institutions.

KEY WORDS. Transfer price, transfer price functions, graphic models of transfer pricing, intermediate product, end product, level of market competition, transfer pricing methods.
\end{abstract}

\section{Introduction}

\footnotetext{
${ }_{* *}^{*}$ This article was translated from its original in Ukrainian.

Taras Savchenko works as an assistant for the Banking Management Department at the Ukrainian Banking Management Academy of the National Bank of Ukraine. In 2003 he graduated with a Master's Degree in Banking Management from the Ukrainian Banking Management Academy in Sumy. He worked as an economist in the Legal Entities Sector, Nominal Transactions Section at the Sumy branch of Kredit Dnipro Bank and as the Chief of Planning and Financial Analysis Section at the Sumy Directorate of Index Bank. Taras Savchenko was a participant in the Young Scholars competition with this paper on 17 May 2006 at Kyiv National Economics University co-sponsored by the Centre for Trade Policy and Law at Carleton University and the University of Ottawa (Ottawa, Canada) and funded by the Canadian International Development Agency (CIDA).
} 
Ukraine recently was granted the status of a market economy, the United states revoked the Jackson-Vanik amendment, and experts forecast that this country will become a member of the World Trade Organization (WTO) by the end of 2006. Ukraine's global economic and financial integration is accompanied by the inflow of foreign investors who bring in new methods of information, financial and material resources management, including those based on transfer pricing.

Transfer pricing methods are most widely introduced by banking institutions. This tendency is developing due to two factors. First, foreign investors are traditionally present in the banking sector, and this sector has recently witnessed a (c) Taras Savchenko, 2006 infln of intomn-tinn-l rapital. Second $\perp$, the majorıty ot $\perp$ oca $\perp$ banking institutions have decentralized system of branches, which facilitates the wider use of transfer pricing methods.

Using transfer prices allows banking institutions to ensure a fair financial assessment of their individual divisions, track the profitability of banking products, and determine the efficiency of management decisions. Transfer pricing methods are widely used to create budgeting and planning systems.

Certain Ukrainian banks actively develop and implement transfer pricing methods, but there are practically no significant studies of this issue in the Ukrainian academic literature. This paper studies the necessary methodological foundations and provides arguments in favor of methods that allow the creation of an effective transfer pricing system.

\section{Overview of recent publications and research}

Ukrainian academic literature provides insufficient coverage of theoretical aspects of transfer pricing and its practical use. Ukrainian researchers K. Zhydko and N. Shulga offer a schematic overview of conceptual foundations of transfer pricing in their 
works $^{1}$. In his article «Methods of Assessing Basic Financial Operations of a Commercial Bank with the Help of the Transfer Pricing System», Ukrainian economist S. Sokolovsky pointed out certain aspects in the application of the transfer pricing system in a banking institution ${ }^{2}$.

Studies by Russian academics, who explore the use of transfer pricing both in the actual economy (N. Vafina) and the banking sector (A. Zubarev, R. Olkhova, M. Rumyantsev), seem to be more diverse and fundamental. ${ }^{3}$ Both Ukrainian and Russian researchers refer to the experience of transfer pricing in developed market economies. The works of American and West European researchers indeed reveal a valuable theoretical and practical study of transfer pricing. ${ }^{4}$

The purpose of this article is to study certain aspects of methodology and methods of transfer pricing in Ukrainian banking institutions (Fig. 1).

\footnotetext{
${ }^{1}$ Zhydko K. Teoretychni osnovy pobudovy systemy transfertnoho tsinoutvorennia u banku, in Visnyk Natsionalnoho banku Ukrainy, 2005, No. 1, p. 52-56.; Shulga N.P. Transfertne tsinoutvorennia yak instrument biudzhetuvannia komertsiynoho banku, in Problemy i perspektyvy rozvytky bankivskoyi systemy Ukrainy, V. 5, Sumy, Mriya LTD, 2002.

2 Sokolovskiy S. Metodyka otsinky osnovnykh finansovykh operatsiy komertsiynoho banku za dopomohoyu systemy transfertnoho tsinoutvorennia, in Visnyk Natsionalnoho banku Ukrainy, 2000, No. 8, p. 3133.

${ }^{3}$ Vafina N.Kh. Transfertnoe tsenoobrazovanie: zarubezhnyi opyt, in Finansy i kredit, 2003, No. 9, p. 30 36; Zubarev A.V. Vnutrenniy hozraschet v banke, transfertnoe tsenoobrazovanie, in Bankovskoe delo (in Russian), 2001, No. 1, p. $14-18$; Olkhova R.G. Transfertnoe tsenoobrazovanie v sisteme upravleniya dokhodnostiu banka, in Bankovskie uslugi (in Russian), 2001, No. 7, p. 34 48; Rumiantsev M.V. Voprosy metodologii i metodiki transfertnoho tsenoobrazovania, in Bankovskie uslugi (in Russian), 2004, No. 2, p. 5-12.

4 Colin Drury. Management and Cost Accounting, Fourth edition, London, International Thomson Business Press, 1996; Tang R. Transfer pricing in the 1990's, in Management Accounting (USA), 1992, February, p. $22-26$.
} 


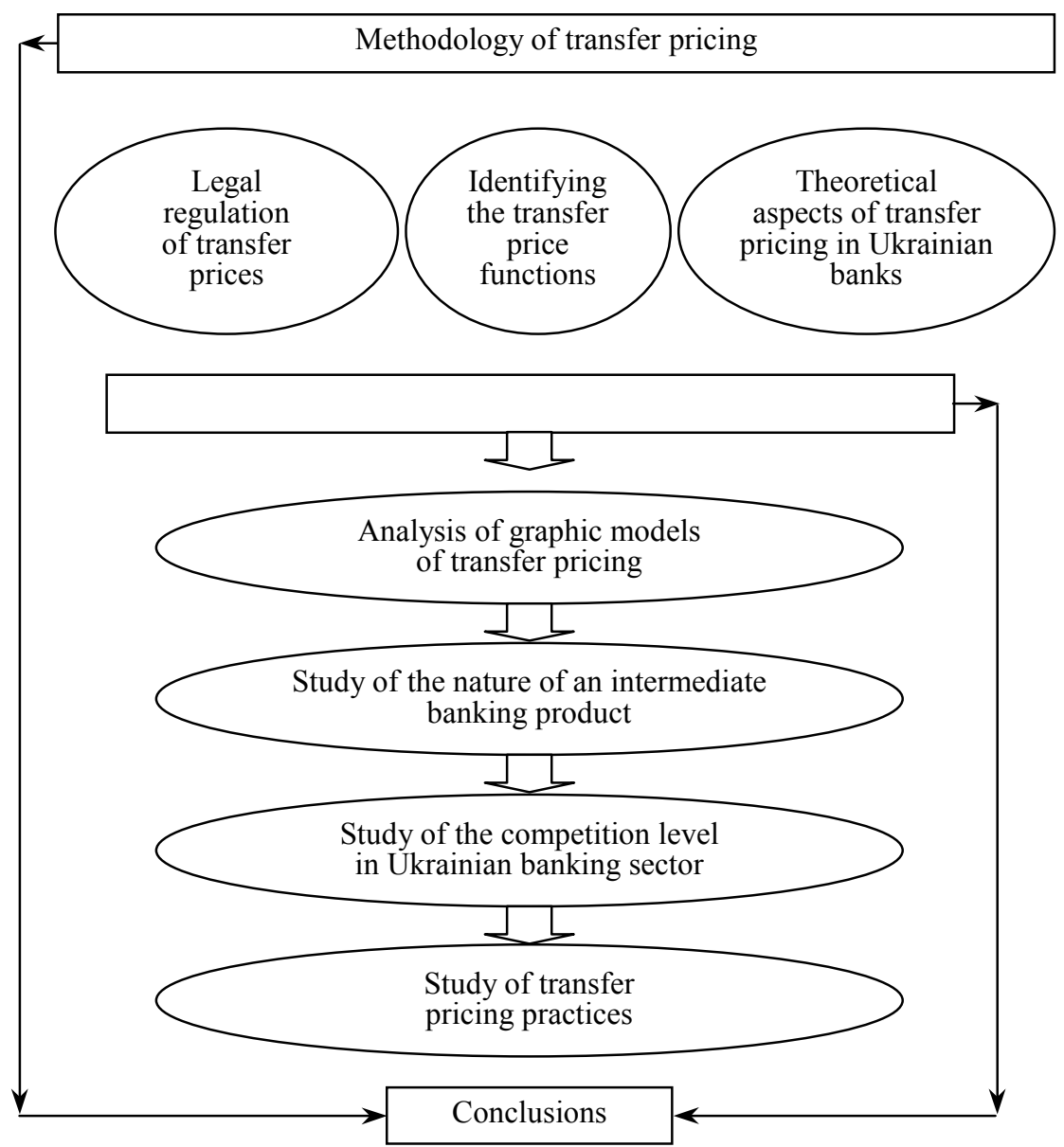

Fig. 1. Flow chart of this article

Methodological aspects of transfer pricing

\section{The Legal Regulation of Transfer Prices}

The legal regulation of transfer pricing is of significant importance when it comes to correctly determining gross revenues and expenses of the divisions of transnational corporations and consequently the calculation of profits. An objective estimate of profit made by a division of a transnational corporation helps to obtain a fair value of tax charges.

The Ukrainian legal code provides no specific act that regulates transfer pricing. However, the Law on Taxation of Companies' Profits indirectly regulates 
internal prices of a transnational corporation. ${ }^{5}$ Paragraph 4 of Article 7 outlines specific aspects of taxation applied to transactions with the entities concerned. According to subparagraph 26 of Article 1 of the Law, such entities include divisions of translational corporations. Gross revenues and expenses of these entities are regulated by comparing prices with the 'regular price' which, in turn, according to subparagraph 20 of Article 1, is a fair market price.

Until the late 1970s, developed market economies controlled the transfer pricing at national levels. The U.K. adopted the relevant law at the end of the 1950s. The Federal Republic of Germany regulated certain domestic issues related to the determination of transfer prices for corporations back in 1965 when it adopted the law on corporations.

Economic globalization intensified the need for transfer pricing regulation at the international level in terms of taxation of transnational corporations. In the 1970s the Organization for Economic Cooperation and Development (OECD) developed principles to avoid double taxation whenever transfer prices are used in international trade. ${ }^{6}$ In 1979 the OECD Tax Committee issued a report called "Transfer Pricing and Multinational Enterprises» for the purpose of establishing the level of transfer prices and their recalculation into market prices in the interests of tax authorities, and in 1994 this Committee issued the document, "Transfer Pricing Guidelines for Multinational Enterprises and Tax Administrations». They were revised in 1996 and 1997 taking into account greater globalization of transnational corporations.

These OECD revisions are flexible, set forth moderate documentation requirements, establish nonhostile relations between tax authorities and transnational corporations, and are characterized as recommendations. According to this regulatory document, national tax authorities may request documentation that discloses the methods used to calculate trans-

\footnotetext{
${ }_{6}^{5}$ Law on Taxation of Companies' Profits of 28 December 1994, at http://zakon.rada.gov.ua.

${ }^{6}$ Vafina N.Kh. Transfertnoe tsenoobrazovanie: zarubezhnyi opyt, in Finansy i kredit, 2003, No. 9, p. $30-36$.
} 
fer prices by international corporations. Thus, the specific scope and degree of details of documents which tax authorities may request need to be established. Tax authorities may audit transnational corporations and determine the fairness of the established level of transfer prices taking market equivalents of those prices as the base. The OECD recommends that both criminal and commercial penalties be imposed for noncompliance with transfer pricing procedures.

The majority of these recommendations were incorporated by Western European countries and the United States in their legislation. For instance, British legislation on transfer prices was adjusted in 1999 as the new Transfer Pricing Rules were adopted. ${ }^{7}$ A major difference of the new version of transfer pricing rules is that they expand the scope of their use: some 40 of corporations are covered by new rules. The new version is fully consistent with the OECD recommendations and provides clear mechanisms on how to impose penalties for noncompliance.

The majority of investigations into transfer prices have been conducted in the U.S., Canada and the U.K.. ${ }^{8}$ For instance, Nissan Company paid 17 billion yen to the U.S. Internal Revenue Service in 1993 for transferring a part of its revenue from the United States to Japan with the help of transfer prices and thus avoided paying U.S. taxes. Another American transnational company Coca-Cola paid significant fines for breaking the tax law in 1994. In the same year, U.S. tax authorities imposed penalties on 392 transnational companies for misuse of transfer prices and charged an additional US\$3.5 billion in taxes. Moreover, 56 \% of U.S corporations and 50 \% of U.K. corporations were audited by U.S. tax authorities in 1996.

Identifying transfer price functions. Transfer pricing is a complex economic method of increasing the efficiency of industry management, the study of which focuses on at least two economic subjects: pricing theory and enterprise economics theory.

\footnotetext{
${ }^{7}$ The New United Kingdom Transfer Pricing Rules, in The International Tax Journal, 1999, p. 58 - 69.

${ }^{8}$ Krylov V.M. Transfertnye tseny: osnovnye funktsyi i problemy, in Finansy i kredit, 2002, No. 7 , p. $20-24$.
} 
Transfer price, as a separate type of price, may be studied from the perspective of general pricing theory. ${ }^{9}$ Today, pricing theory is dominated by an integrated approach to understanding the substance of price, which combines the Karl Marx theory of value, research by A. Marshal and A. Pigue, marginal theory and individual choice theory by P. Samuelson. The latter two theories study the price phenomenon predominantly from the perspective of factors on the demand side, while the theory of value examines factors that affect production from the supply side, with Marshal and Pigue taking demand and supply as equally important pricing factors.

The economic substance of transfer price may be explained with the help of value theory and market theories of price, without changing the principles of these theories, on condition that the following assumption is accepted: the divisions of one legal entity are recognized as individual economic agents (economic entities). This assumption helps to introduce the concepts of 'in-house value' and 'in-house marginal utility' to get better insight into transfer price within the value and marginal price theories. Therefore, a comprehensive interpretation of transfer pricing as a specific type of price depends on the level of economic freedom exercised by the divisions of an organization in terms of economic decision making, including decisions on establishing the level of in-house prices. In an organization with highly decentralized management functions, divisions have greater discretion in economic decision making. The transfer price in such organizations internally has all five functions that prices normally have: functions of accounting and measuring, balancing, stimulation, redistribution, and location of economic activity. ${ }^{10}$

According to the theory of enterprise economics, the transfer price should be viewed as an important component of the internal economic mechanism of an enterprise which is based on decentralized management and expanded responsibility of its divisions

\footnotetext{
${ }^{9}$ Utkin Ye.A. Tseny. Tsenoobrazovanie. Tsenovaya politika: Uchebnik, Moscow, Ekmos, 1997.
${ }^{10}$ Yesipov V.Ye. Tseny i tsenoobrazovanie: Uchebnik, 3rd revised edition, St-Petersburg, Piter, 1999.
} 
for their own business results. From this perspective, the main functions of transfer prices include financial incentives for personnel based on the performance results of divisions, and the distribution of costs at their place of origin. O. I. Volkov ${ }^{11}$ presented a comprehensive interpretation of the system of in-plant economic relations and internal pricing as one of its major components. From the perspective of the theory of enterprise economics, the transfer price is a method of achieving the production objectives of an enterprise.

Examining theoretical aspects of transfer pricing in Ukrainian banking institutions. In order to extrapolate the results of this study of methodological principles of transfer pricing to banking institutions, certain aspects of the use of this type of pricing in monetary institutions should be highlighted.

First, the legal regulation of transfer pricing in banking institutions appears to be especially important in view of the active inflow of international capital in the national banking system and the high probability that the Ukrainian parliament will pass amendments to the Law on Banks and Banking Activity ${ }^{12}$ to liberalize the opening of branches by foreign banks in Ukraine. Secondly, the term 'transfer price' seems to be more appropriate when it comes to describing the pricing process within a banking institution, while its equivalent 'in-house price' should rather be used to denote pricing in companies of the non-financial sector of the economy .

To maintain the functional and meaningful weight of 'transfer price' as an economic concept, it is necessary to restrict its use only to pricing within one legal entity. This restriction needs to be made whenever the concept is defined in economic reference and should be taken into account when this concept is defined in the legislation. It is not expedient to use it to denote the movement of goods, work and services between legal entities which are

\footnotetext{
${ }_{12}^{11}$ Ekonomika predpriyatiya, Ed. by O.I. Volkov, Moscow, Infra-M, 1997.

${ }^{12}$ Law on Banks and Banking Activity of 7 December 2000, at http://zakon.rada.gov.ua.
} 
members of a certain association which is not a legal entity. Under Article 9 of the Law on Banks and Banking Activity, banks may establish the following bank associations: a bank corporation, a bank holding group, and a financial holding group. The Law provides that a bank corporation is a legal entity (bank), whose founders and stockholders are other banks, while a bank holding group and a financial holding group are bank associations. Therefore, the term 'transfer pricing' may be used to denote pricing within a banking corporation, but it should not be used to denote pricing within a banking holding group or a financial holding group.

\section{Methods of transfer pricing}

Analysis of graphic models of transfer pricing. The theory of marginal analysis is universal and the most common method for examining the efficiency of price related decision making within a company. ${ }^{13}$ Marginal analysis is widely applied in modern theoretical studies to determine the firm efficiency in markets with various levels of competition. The graphic models of transfer pricing designed according to marginal analysis will now be examined. ${ }^{14}$

We propose to study three graphic models of transfer pricing, which describe the company's performance in the absence and in the presence of an external market for the intermediate product and take into account the competition in this market. It should be noted that these graphic models were created based on empirical data of companies in the tangible sector of the economy, but they may also be used to model the operation of financial institutions in view of the universal nature of the method of marginal analysis.

The following assumptions were used in the models:

${ }^{13}$ Campbell R. McConnell, Stanley L. Brue. Economics: printsypy, problemy i politika, translated from English, 11th edition, Kiev, Khagar-Demos, 1993; Paul A. Samuelson, William D. Nordhouse. Mikroeconomika, translated from English, Kiev, Osnovy, 1998.

${ }^{4}$ Colin Drury. Management and Cost Accounting, fourth edition, London, International Thomson Business Press, 1996. 
- The company is composed of two divisions: a division that produces the intermediate product (supply division) and a division that consumes this product by transforming it into an end product (consuming division);

- The intermediate product is subject to transfer pricing and is used for production by the company's end product which is sold to external consumers;

- A theoretically correct transfer price is the price that encourages the divisions to work at the level of end product output which is optimal for the entire company.

Adaptation of these assumptions to the specific environment of a banking institution would be as follows:

$\checkmark$ Supply divisions in a banking institution could be the divisions that generate the bank's resources (deposit divisions) while the consuming divisions are the divisions that allocate the collected resources (credit divisions);

$\checkmark$ The intermediate banking product is the amount of financial liabilities (this argument was supported in the previous section of this article);

$\checkmark$ A theoretically correct transfer price is the price that helps to optimize the operation of the entire banking institution.

1. Model of transfer pricing in the presence of a competitive external market for the intermediate product. ${ }^{15}$ The competitive market is the market of absolute competition with a large number of sellers and buyers who cannot influence it. From the short term perspective, the selling price is represented as a horizontal line. (Fig. 2).

External market price for the intermediate product is established at the OP level and, since the external market is assumed to be competitive, the marginal revenue from the sale of intermediate product is fixed and is represented by the horizontal line PE. NMR is the line of net marginal revenue of the division that consumes the intermediate product and sells the end product, which represents the difference between the marginal

\footnotetext{
${ }^{15}$ Charles I. Transfer-price solution where market exists, in Accountancy, 1986, July, p. 96-99.
} 
revenue and marginal cost of this division less the transfer price paid to the supply division. The transfer price will be established at the level of market price for the intermediate product on the external competitive market (OP).

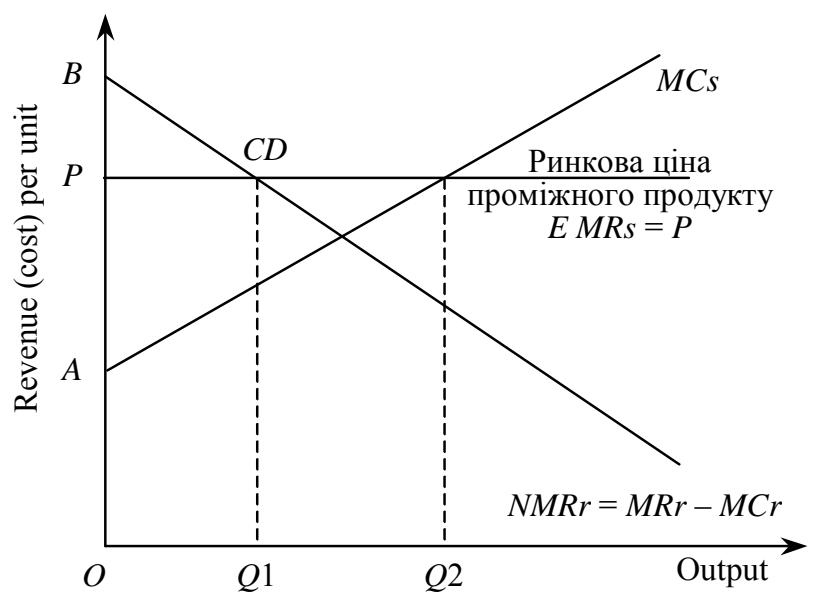

Fig. 2. Transfer pricing in the presence of a competitive external

market for the intermediate product

With this transfer price, the consuming division will require the volumes of intermediate product equal to $0 Q 1$ as this would ensure the parity of its marginal cost $(P=M C r)$ and revenue (NMRr). The consuming division may take the intermediate product both from the supply division and external market at the same price. The supply division will also be able to sell the intermediate product both in the in-house and external markets at the same price. To achieve the optimum level of production $(M C S=M R S)$, the supply division may produce the intermediate product in volumes equal to 002 and sell any additional volumes of its product (Q1Q2) in the external market while the volume $O Q 1$ will be supplied to the consuming division at the transfer price.

It should be noted that the net marginal revenue of the entire company is represented by the BCDE curve and the most profitable level of production for the entire company will be at the crossing point of marginal cost of the entire company as repre- 
sented by $A D E$ curve, i.e. in point $D$. Therefore, the company should ensure the production in volumes equal to 0Q2, which is equivalent to the optimum volume of intermediate product manufactured by the supply division. Therefore, on condition of the presence of a competitive external market for the intermediate product, the orientation of transfer pricing to the external market price will stimulate company divisions to ensure optimum production volumes.

2. Transfer pricing in the absence of an external market for the intermediate product. Sometimes the external market for the intermediate product is noncompetitive or nonexistent (Fig. 3).

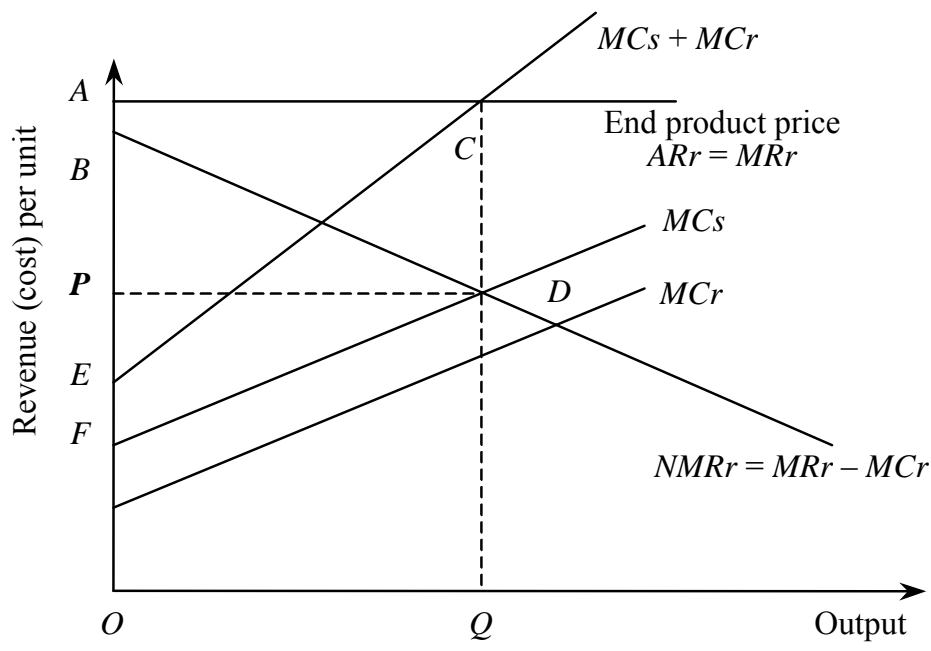

Fig. 3. Transfer pricing in the absence

of an external market for the intermediate product.

When the division which supplies the intermediate product has no production restrictions, the transfer price should be set at the OP level (the PD line represents the marginal revenue of the supply division), which ensures maximum revenue for the intermediate product supply division at the optimum level of end product output for the entire company. A more 
detailed analysis of this graphic model is offered in the works of foreign researchers. ${ }^{16}$

3. Transfer pricing in the presence of a noncompetitive external market for the intermediate product. The optimum transfer price, which would stimulate company divisions to maintain the necessary production level (OQ3) corresponds to OPt value (ensures optimization of revenue for the supply division and the company on the whole). The supply division will maximize its revenue by selling the intermediate product in amounts equal to OQ1 at price OPe on the external market and selling any additional amount (Q1Q3) at price oPt to the consuming division (Fig. 4).

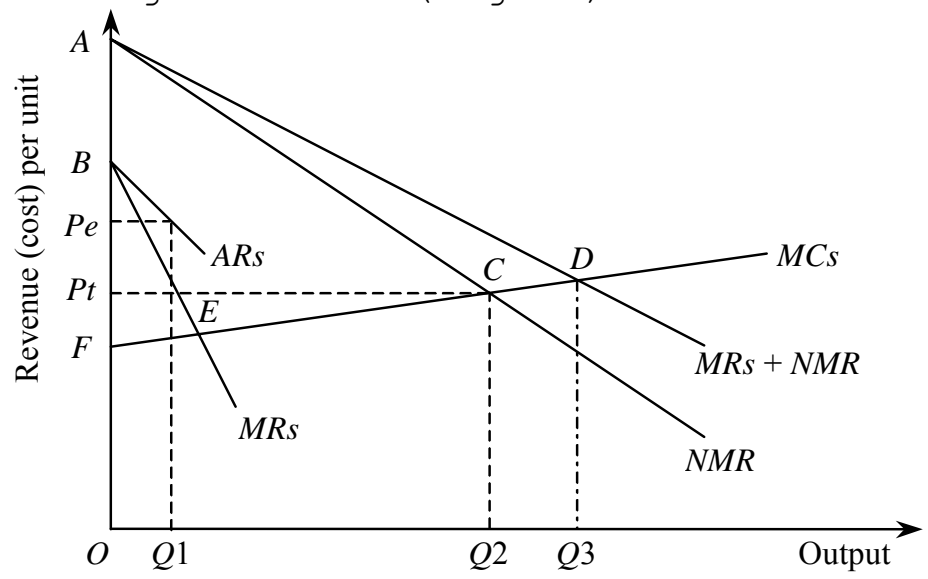

Fig. 4. Transfer pricing in the presence of a noncompetitive external market for the intermediate product

This solution is also an optimum solution for the consuming division which needs to consume the intermediate product in amount OQ2, where section OQ1 equals Q2Q3, and therefore section OQ2 equals Q1Q3. A more detailed analysis of this graphic model can be found in the works of foreign researchers. ${ }^{17}$

${ }^{16}$ Charles I. The economics approach to transfer price, in Accountancy, 1985, June, p. 110-112; Colin Drury. Management and Cost Accounting, fourth edition, London, International Thomson Business Press, 1996.

Colin Drury. Management and Cost Accounting, fourth edition, London, International Thomson Business Press, 1996 
Study of the nature of intermediate banking products. In order to make practical use of the graphic models of transfer pricing analyzed above, the economic nature of the intermediate banking product needs to be examined.

The contemporary research literature outlines four major approaches to determining the nature of 'banking product' and 'banking service': monetary, legal, marketing, and client approaches. ${ }^{18}$ The main postulates of the above theories may be analyzed from the perspective of two understandings of the nature of banks.

The first approach understands a commercial bank as a specific enterprise that manufactures a unique product (goods of unique nature in the form of money and payment instruments) and perceives the market of banking products as the 'producer's (bank's) market'. From this perspective, the banking product is conceived of as a certain amount of monetary liabilities (monetary approach). The banking service, in its turn, is interpreted as a 'service of a monetary nature', a service that helps move the money from account to account or creates monetary funds.

The second approach is built on the understanding of a commercial bank as a financial intermediary whose primary function is to serve the needs of its clients and perception of the market of banking products as the 'consumer's (client's) market'. Based on this logic, the banking product is interpreted as a form of a banking service which, in its turn, is aimed at satisfying the client's needs (marketing and client approach). Therefore, the banking service is viewed as the functional substance of the bank whereas the banking product is a form of this substance. In other words, the banking product and service are dialectically interrelated as the form and substance respectively.

Taking into account the specific methodology and methods of using transfer pricing, this article understands 'a bank' as a specific enterprise that produces a unique product and 'a banking service' is

\footnotetext{
${ }^{18}$ Perekhozhev V.A. Sovremennye podhody k ponimaniyu kategoriy 'bankovskiy produkt', 'bankovskaya usluga' $i$ 'bankovskaya operatsiya', in Finansy i kredit (in Russian), 2002, No. 21, p. 23-33.
} 
understood as a certain amount of monetary liabilities.

Unlike other sectors of the economy, the financial sector on the whole and the banking system in particular have a common (universal) substantive platform for all products which they produce. Any product of a financial enterprise is based on monetary liabilities of a certain amount. Foreign banking institutions offer over three hundred banking products; while Ukrainian banks offer a half or one third of that number of services, all of them are based on certain monetary liabilities. Intermediate banking product is also a form of monetary liabilities and does not differ in substance from the end banking product.

Therefore, the intermediate banking product as the object of transfer pricing has its analogues in external markets. For Ukraine, these markets include the Interbank Credit Market, Interbank Currency Exchange, a market for deposits and credits for legal entities and individuals, etc. One may question the objectiveness of information from the above external markets, but the very fact of their existence is undisputable.

Therefore, we came to the conclusion that the intermediate banking product has its market analogues. By analyzing the level of competition in the Ukrainian banking market, we will determine which of the graphic models of transfer pricing may become the theoretical basis for developing an effective transfer pricing method.

Study of the level of competition in the Ukrainian market of banking products. Matching real markets with theoretical models of markets (pure competition market, monopolistic competition market, oligopoly, and pure monopoly) is one of the most complex issues in microeconomics since the functioning markets are permanently influenced by various economic and sociopolitical factors.

The level of competitiveness of the Ukrainian market of banking products can be determined by applying the market competitiveness assessment methods which are most commonly used in the world. The subject matter for this study is the market of banking 
products in general without division into banking transactions and services. Due to the lack of necessary information, this research does not take into account the market of nonbanking products from nonbanking financial institutions.

First to be analyzed is the Ukrainian banking market with the help of the method of formal logic. Using the formal characteristics (Table 1) provided in the academic literature ${ }^{19}$, the following table is formed.

Table 1. Formal characteristics of basic market models

\begin{tabular}{|c|c|c|c|c|}
\hline \multirow{2}{*}{$\begin{array}{c}\text { Formal } \\
\text { character- } \\
\text { istics } \\
\text { of basic } \\
\text { market mod- } \\
\text { els }\end{array}$} & \multicolumn{4}{|c|}{ Market model } \\
\hline & $\begin{array}{c}\text { Pure competi- } \\
\text { tion }\end{array}$ & $\begin{array}{l}\text { Monopolistic } \\
\text { competition }\end{array}$ & Oligopoly & Pure monopoly \\
\hline $\begin{array}{l}\text { Number of } \\
\text { companies }\end{array}$ & Very many & Many & Several & One \\
\hline $\begin{array}{l}\text { Type of } \\
\text { product }\end{array}$ & $\begin{array}{l}\text { Standard- } \\
\text { ized }\end{array}$ & $\begin{array}{l}\text { Differenti- } \\
\text { ated }\end{array}$ & $\begin{array}{l}\text { Standardized } \\
\text { or differen- } \\
\text { tiated }\end{array}$ & Unique \\
\hline $\begin{array}{l}\text { Price con- } \\
\text { trol }\end{array}$ & None & $\begin{array}{l}\text { Some con- } \\
\text { trol but } \\
\text { within cer- } \\
\text { tain limits }\end{array}$ & $\begin{array}{l}\text { Limited, } \\
\text { significant } \\
\text { in case of } \\
\text { collusion }\end{array}$ & Significant \\
\hline $\begin{array}{l}\text { Market ac- } \\
\text { cess }\end{array}$ & $\begin{array}{l}\text { Very easy, } \\
\text { no barriers }\end{array}$ & $\begin{array}{l}\text { Compara- } \\
\text { tively easy }\end{array}$ & $\begin{array}{l}\text { Significant } \\
\text { barriers }\end{array}$ & $\begin{array}{l}\text { Access } \\
\text { blocked }\end{array}$ \\
\hline $\begin{array}{l}\text { Non-price } \\
\text { competi- } \\
\text { tion }\end{array}$ & None & $\begin{array}{l}\text { Significant } \\
\text { focus on ad- } \\
\text { vertisement, } \\
\text { trademarks, } \\
\text { brands, etc. }\end{array}$ & $\begin{array}{lr}\text { Very typi- } \\
\text { cal, espe- } \\
\text { cially } \\
\text { case } \\
\text { product } \\
\text { differen- } \\
\text { tiation }\end{array}$ & $\begin{array}{l}\text { Primarily } \\
\text { the ad- } \\
\text { vertisement } \\
\text { of the com- } \\
\text { pany's so- } \\
\text { cial activ- } \\
\text { ity }\end{array}$ \\
\hline
\end{tabular}

The results of the analysis of the Ukrainian banking market based on the above criteria are provided in Table 2. The degree of correspondence between a formal characteristic and the real situation is ranged with the help of points: 0 - does not correspond; 0.5 - partially corresponds; 1 - fully cor-

${ }^{19}$ Campbell R. McConnell, Stanley L. Brue. Economics: printsypy, problemy i politika, translated from English, 11th edition, Kiev, Khagar-Demos, 1993. 
responds. The market of pure competition and the market of monopolistic competition received the highest score under the formal analysis method - 3 and 2.5 points respectively. Therefore, the Ukrainian market of banking products may be characterized as one that partially corresponds to the theoretical model of pure competition market and partially corresponds to the monopolistic competition market.

Table 2. Specific features of the Ukrainian banking market

\begin{tabular}{|c|c|c|c|c|c|}
\hline \multirow[b]{2}{*}{$\begin{array}{l}\text { Specific } \\
\text { features }\end{array}$} & \multicolumn{4}{|c|}{ Market model, correspondence points } & \multirow[b]{2}{*}{$\begin{array}{c}\text { Ukrainian } \\
\text { banking market }\end{array}$} \\
\hline & $\begin{array}{l}\text { Pure } \\
\text { competi- } \\
\text { tion }\end{array}$ & $\begin{array}{l}\text { Monopo- } \\
\text { listic } \\
\text { competi- } \\
\text { tion }\end{array}$ & $\begin{array}{l}\text { Oligop- } \\
\text { oly }\end{array}$ & $\begin{array}{l}\text { Pure } \\
\text { monop- } \\
\text { oly }\end{array}$ & \\
\hline $\begin{array}{l}\text { Number of } \\
\text { companies }\end{array}$ & 1 & 0.5 & 0 & 0 & Very large \\
\hline $\begin{array}{l}\text { Type of } \\
\text { product }\end{array}$ & 1 & 0 & 0.5 & 0 & $\begin{array}{l}\text { Mostly stan- } \\
\text { dardized, } \\
\text { sometimes } \\
\text { differenti- } \\
\text { ated }\end{array}$ \\
\hline $\begin{array}{l}\text { Price con- } \\
\text { trol }\end{array}$ & 1 & 0.5 & 0 & 0 & $\begin{array}{l}\text { Almost none, } \\
\text { sometimes in- } \\
\text { significant }\end{array}$ \\
\hline $\begin{array}{l}\text { Market ac- } \\
\text { cess }\end{array}$ & 0 & 1 & 0 & 0 & $\begin{array}{l}\text { Comparatively } \\
\text { easy }\end{array}$ \\
\hline $\begin{array}{l}\text { Non-price } \\
\text { competi- } \\
\text { tion }\end{array}$ & 0 & 0.5 & 0.5 & 0 & $\begin{array}{l}\text { Existing but } \\
\text { insignificant }\end{array}$ \\
\hline $\begin{array}{l}\text { Total } \\
\text { points }\end{array}$ & 3 & 2.5 & 1 & 0 & \\
\hline
\end{tabular}

The next approach to measuring market competition is based on examining 'the relative markup' or the Lerner index. This method of measuring the monopoly power of a company was proposed in 1934 by economist Abba Lerner and so it was called the Lerner index of monopoly power. ${ }^{20}$ This test is expressed by the following mathematical formula: 1996.

${ }^{20}$ Robert S. Pindyke, Daniel L. Rubinfeld. Mikroeconomika, translated from English, Kiev, Osnovy, 


$$
I_{l}=\frac{P-M C}{P}=\frac{1}{E},
$$

$I_{I}$ - the Lerner index of monopoly power;

$P$ - price;

$M C$ - marginal cost;

$E$ - demand elasticity for the company's goods.

The Lerner index is always between zero and one. $\mathrm{P}=\mathrm{MC}$ represents the absolutely competitive company, and so $\mathrm{L}=0$. The greater the index, the higher degree of monopoly power the company has on the market. To analyze the entire market of banking products, we propose to adapt Formula 1 by multiplying its numerator and denominator by the total volume of production of banking products by all Ukrainian banks in 2005 (Q). Therefore, the derivative $P$. Q will reflect the total revenues while derivative $M C \cdot Q$ will reflect total costs of the Ukrainian banking system in 2005 (for the purposes of our analysis, we assume that marginal costs (MC) are equal to average total costs $(A T C)$. According to the official site of the National Bank of Ukraine $(N B U)^{21}$ in 2005, the total revenues and costs of banks were $27,480.6$ million hryvnia and 25,073.1 million hryvnia, respectively. Using the adapted variant of the Lerner index, we will find that the relative markup in the Ukrainian banking system in 2005 was 0.0876 of the price for the banking product. This markup level, comparing to other sectors of the economy, is insignificant and characterizes the domestic market of banking products as quite competitive.

\section{Now, we propose to use the method of measuring the market concentration with the help of the Hirschmann-Herfindale index ${ }^{22}$ :}

$$
I_{H H}=S_{1}^{2}+S_{2}^{2}+S_{3}^{2}+\ldots+S_{n}^{2},
$$

$I_{H H}$ - the Hirschmann-Herfindale index;

$S_{1}$ - market share of the largest company;

$S_{2}$ - market share of the next largest company;

\footnotetext{
${ }_{22}^{21} \mathrm{http}: / /$ bank.gov.ua

${ }^{22}$ Nureev R.M. Osnovy ekonomicheskoy teorii: Mikroekonomika, Moscow, Vyshaya shkola, 1996.
} 
$\bar{S}_{n}$ - market share of the smallest company.

In order to calculate this index, we use the data on the share of the company's products in its sector, i.e. the company's market share. It is envisaged that the larger the company's share in its sector, the greater the potential possibility that the monopoly will strengthen. It should be noted that the market share of a banking institution could be assessed by determining the share of the bank's assets compared to the total assets of the banking system. This approach depends on the specific nature of the banking activity where the assets (or liabilities) fully reflect the sale volumes of banking products.

If there is only one company on the market (i.e. when we deal with a pure monopoly), $S_{1}=100 \%$, and $I_{H H}$ $=10000$. If there are 100 similar companies in the sector, $S_{i}=1 \%$, and $I_{\mathrm{HH}}=100 \cdot S_{i}^{2}=100$. In the U.S., a market is considered highly monopolized when the Hirschmann-Herfindale index exceeds 1,800. This index is widely used for antimonopoly purposes.

Having calculated the market share of each of 163 banks licensed by the NBU to perform banking operations as of 1 January 2006, based on the data from the official NBU site ${ }^{23}$, and having summed their squares, we obtained the HirschmannHerfindale index for the Ukrainian banking system. This index is 389.39 points, taking into account sales, which again confirms that there is no excessive concentration in the domestic market of banking products. A more detailed calculation of the index is provided in Annex 1.

And finally, let's use a simpler and more transparent and clear method for measuring market power proposed by Paul A. Samuelson - William D. Nordhaus. ${ }^{24}$ The essence of this method consists of examining the market shares of market leaders. Based on the empirical data of the U.S. economy, authors of this method proposed the following criteria for de-

\footnotetext{
${ }_{24}^{23}$ http:// bank.gov.ua

${ }^{24}$ Paul A. Samuelson - William D. Nordhaus. Mikroeconomika, translated from English, Kiev, Osnovy, 1998 .
} 
fining market competitiveness: a market has a high degree of concentration if the four largest companies control over $60 \%$ of the market, while the four largest companies would produce not more than $20 \%$ of products on the markets with a low degree of concentration.

Leaders in the Ukrainian banking system are Pryvatbank - 10.31 \% of the market, Aval - 9.00\% of the market, Prominvestbank - 6.82 \% of the market, and Ukrsotsbank - $5.03 \%$ of the market. These leading banks together control 31.17 of the Ukrainian market of banking products. A more detailed calculation of the index is provided in Annex 1. Therefore, on the one hand, we cannot say that the market concentration is low, but on the other hand, the four leading banks control about one third of the market, which is a relatively high level. Because of the lack of access to information, this study does not take into account the possibility that one owner may control several banks.

An analysis of the Ukrainian market of banking products shows that it is quite competitive and none of its participants has the monopoly power to control prices, except the National Bank of Ukraine. The NBU, however, is not a regular player in the banking market as it performs a specific function of regulating and ensuring the stability of the national currency.

Based on the research results of the nature of the intermediate banking product and the level of competition in the domestic banking market, we conclude that the strategy for developing the transfer pricing methods should be a graphic model which provides for the existence of a competitive external market for intermediate products (Fig. $2)$. This model recognizes the need to focus on market indicators during the development of transfer pricing method.

\section{Practical importance of the research}

The practical importance of this research can be verified by comparing its results with global and 
national practices of transfer pricing. The research by Roger Y.W. Tang can be taken as the base ${ }^{25}$ to analyze the practice of transfer pricing in $500 \mathrm{ma}-$ jor American corporations (corporations included in the Fortune 500 Index). The research was conducted in 1990 through a survey that covered 143 respondents who represented 28.6 \% of the total number of corporations included in the research. (Table 3 ).

Table 3. Use of transfer pricing methods by major U.S. corporations, \%

\begin{tabular}{|l|c|c|c|c|}
\hline \multirow{2}{*}{$\begin{array}{l}\text { Transfer pricing meth- } \\
\text { ods }\end{array}$} & \multicolumn{2}{|c|}{ U.S. business } & \multicolumn{2}{|c|}{ International business } \\
\hline Based on costs & 1990 & 1977 & 1990 & 1977 \\
\hline $\begin{array}{l}\text { Based on market } \\
\text { prices }\end{array}$ & 46.2 & 50.4 & 41.4 & 46.6 \\
\hline $\begin{array}{l}\text { Based on negotia- } \\
\text { tions }\end{array}$ & 36.7 & 31.5 & 45.9 & 39.0 \\
\hline $\begin{array}{l}\text { Other methods } \\
\text { Total }\end{array}$ & 16.6 & 18.1 & 12.7 & 13.6 \\
\hline
\end{tabular}

American researchers Roger Y.W. Tang, C.K. Walter and R.H. Raymond ${ }^{26}$ conducted a similar survey in 1979 (Table 3). Comparing the results of the 1977 and 1990 surveys, we notice a general tendency towards the reduced use of transfer pricing methods based on costs and negotiations and increased use of transfer pricing methods based on market prices by more than 5 points.

The experience of using transfer pricing methods in other developed countries is illustrated in Table $4 .{ }^{27}$

\footnotetext{
${ }^{25}$ Tang R. Transfer pricing in the 1990's, in Management Accounting (USA), 1992, February, p. $22-$ 26.

${ }^{26}$ Roger Y.W. Tang, C.K. Walter, and R.H. Raymond. Transfer Pricing - Japanese vs. American Style, in Management Accounting, 1979, January, p. 12-16.

Drury C., Braund S., Osborne P. and Tayles M. A Survey of Management Accounting Practices in UK Manufacturing Companies, London, ACCA Research Paper, Chartered Association of Certified Accountants, 1993
} 
Table 4. Use of transfer pricing methods, \%

\begin{tabular}{|l|c|c|c|c|}
\hline \multirow{2}{*}{$\begin{array}{l}\text { Transfer pricing } \\
\text { methods }\end{array}$} & Japan & U.S & Austria & Canada \\
\cline { 2 - 5 } & 1979 & 1990 & 1991 & 1992 \\
\hline $\begin{array}{l}\text { Based on market } \\
\text { prices }\end{array}$ & 34 & 37 & 13 & 34 \\
\hline $\begin{array}{l}\text { Based on costs } \\
\text { Based on negotia- }\end{array}$ & 19 & 46 & 65 & 46 \\
\hline $\begin{array}{l}\text { tions } \\
\text { Other methods }\end{array}$ & 1 & 16 & 11 & 18 \\
\hline
\end{tabular}

As one can see from Table 4, about half of the companies rely on their own costs in establishing transfer prices. This is explained by the lack of competitive external markets for many intermediate products for which transfer pricing is done. At the same time, more than one third of companies are developing transfer pricing systems based on market prices.

In April 2006 this author conducted a survey on transfer pricing practices in Ukrainian banking institutions. The survey was made by distributing questionnaires among 55 banks with the biggest assets, which together comprise 33.7 of the total banks licensed by the National Bank of Ukraine to conduct banking operations as of 01.01 .2006 . The assets of the banks included in the survey totaled 88.3 \% of all assets of the Ukrainian banking system as of 01.01 .2006 . Other balance sheet ratios of this group of banks were approximately on the same level. Therefore, the sampling may be considered as representative in view of the market share of the banks covered by this survey. As of now, 16 responses were received, 29 of the total number of respondents. Representatives of six banks noted that they are not using the transfer pricing system but they plan to introduce it in the nearest future. Representatives of ten banks confirmed that they are using the transfer pricing system. Certain survey results re- 
lated to transfer pricing methods and the period of their use are provided in Table 5.

As we can see, the majority of banking institutions are using both market indicators and their own costs to determine the level of transfer prices. These results can be rather explained by insufficient reliability, promptness and efficiency of information arriving from the markets of end banking product in Ukraine. It should also be noted that the Ukrainian banks have little experience of using transfer prices (only one banking institution uses transfer prices for more than 5 years) and there is a need to further improve this instrument of financial management.

Table 5. Using transfer pricing methods in Ukrainian banking institution

\begin{tabular}{|c|c|c|c|c|}
\hline \multirow[b]{2}{*}{$\begin{array}{c}\text { Transfer pricing meth- } \\
\text { ods }\end{array}$} & \multicolumn{2}{|c|}{$\begin{array}{c}\text { Certain aspects } \\
\text { of the used methods }\end{array}$} & \multicolumn{2}{|c|}{ Period of use } \\
\hline & $\begin{array}{l}\text { Number } \\
\text { of re- } \\
\text { sponses }\end{array}$ & Share ( $\%)$ & $\begin{array}{c}\text { Less than } \\
5 \text { years } \\
\text { (number } \\
\text { of re- } \\
\text { sponses) }\end{array}$ & $\begin{array}{c}\text { More than } \\
5 \text { year } \\
\text { (number } \\
\text { of re- } \\
\text { sponses) }\end{array}$ \\
\hline $\begin{array}{l}\text { Focus on market in- } \\
\text { dicators }\end{array}$ & 1 & 10 & 1 & \\
\hline Focus on costs & 1 & $10 \div$ & 1 & \\
\hline $\begin{array}{l}\text { Focus on market in- } \\
\text { dicators and costs }\end{array}$ & 6 & $60 \div$ & 6 & 1 \\
\hline Other & 2 & $20 \div$ & 2 & \\
\hline Total & 10 & $100 \div$ & 9 & 1 \\
\hline
\end{tabular}

\section{Conclusions}

The new realities of increasing integration processes in the financial sector of Ukraine's economy objectively encourage the use of innovative methods of doing business. Transfer pricing is one such method. It is not common in the domestic practice but is widely used in developed market economies. This research offers a comprehensive and systematic 
analysis of methodology and methods of transfer pricing in Ukrainian banking institutions.

The research has prompted the following conclusions:

- The issue of legal regulation of transfer pricing should be addressed as soon as possible by way of the adoption of special laws and regulations complying with OECD recommendations.

- The functions of transfer prices should be identified in the framework of the general theory of pricing and the theory of enterprise economics.

- The term 'transfer pricing' may be used with reference to pricing within a banking corporation as a separate legal entity.

- Graphic models that help to determine transfer prices were analyzed, and it was concluded that, based on the study of the nature of intermediate banking product and competition level on the Ukrainian market of banking products, transfer prices for intermediate banking products should be established based on market indicators.

- The transfer pricing practices in Ukrainian banks have been studied.

It should be noted that the study of methods that help to create an effective transfer pricing system should not be limited to the nature of the intermediate banking product and analysis of the competition level at the banking market. Further research could focus on the following issues:

$\checkmark$ optimum balance between decentralization and concentration of the management structure of an organization; this issue was examined in detail by David J.H. Watson and John V. Baumler. ${ }^{28}$ The authors believe that the transfer pricing system based on contract transfer prices will ensure an optimum balance between decentralization and integration of the management structure of an organization.

$\checkmark$ Approaches to efficient forecasting of any transfer pricing method based on discriminating

${ }^{28}$ Watson D.H. and Baumler J.V. Transfer pricing: a behavioural context, in Accounting Review, $1975,50(3)$, p. $466-474$.

${ }_{29}$ Mostafa A., Sharp J. and Howard K. Transfer pricing - survey using discriminant analysis, in Omega, 1984, 12(5), p. 465-474. 
Adapting the dual transfer pricing system for use by local banking institutions ${ }^{30}$. This system is based on blending two approaches to transfer pricing: the market method for divisions that buy the intermediate product on the internal market and sell the processed end product on the external market, and the costs method for divisions that produce the intermediate product and sell it to other divisions.

This article will be useful to government agencies involved in developing the legal regulation of transfer prices and companies with decentralized management structure, which would like to improve their system of internal financial management, as well as other readers who wish to learn more about innovative methods of financial management.

\section{References}

1. Vafina N.Kh. Transfertnoe tsenoobrazovanie: zarubezhnyi opyt, in Finansy i kredit, 2003, No. 9, p. 3036 .

2. Yesipov V.Ye. Tseny i tsenoobrazovanie: Uchebnik, 3rd revised edition, St-Petersburg, Piter, 1999.

3. Zhydko K. Teoretychni osnovy pobudovy systemy transfertnoho tsinoutvorennia u banku, in Visnyk Natsionalnoho banku Ukrainy, 2005, No. 1, p. 52-56.

4. Law on Banks and Banking Activity of 7 December 2000, at http://zakon.rada.gov.ua.

5. Law on Taxation of Companies' Profits of 28 December 1994, at http://zakon.rada.gov.ua.

6. Zubarev A.V. Vnutrenniy hozraschet $V$ banke, transfertnoe tsenoobrazovanie, in Bankovskoe delo (in Russian), 2001, No. 1, p.14-18.

7. Campbell R. McConnell, Stanley L. Brue. Economics: printsypy, problemy i politika, translated from English, 11th edition, Kiev, Khagar-Demos, 1993.

8. Krylov V.M. Transfertnye tseny: osnovnye funktsyi i problemy, in Finansy i kredit, 2002, No. 7, p. 20-24.

9. Moskalenko V.P. Ekonomicheskie novatsii: poisk i vnedrenie, Sumy, Dovkillia, 2004.

10. Nureev R.M. Osnovy ekonomicheskoy teorii: Mikroekonomika, Moscow, Vyshaya shkola, 1996.

${ }^{30}$ Adelberg, A. Resolving conflicts in intracompany transfer pricing, in Accountancy, 1986, November, p. $86-89$. 
11. Olkhova R.G. Transfertnoe tsenoobrazovanie V sisteme upravleniya dokhodnostiu banka, in Bankovskie uslugi (in Russian), 2001, No. 7, p.34-48.

12. Perekhozhev V.A. Sovremennye podhody k ponimaniyu kategoriy 'bankovskiy produkt', 'bankovskaya usluga' i 'bankovskaya operatsiya', in Finansy i kredit (in Russian), 2002, No. 21, p. 23-33.

13. Paul A. Samuelson - William D. Nordhaus. Mikroeconomika, translated from English, Kiev, Osnovy, 1998.

14. Robert S. Pindyke, Daniel L. Rubinfeld. Mikroeconomika, translated from English, Kiev, Osnovy, 1996.

15. Rumiantsev M.V. Voprosy metodologii i metodiki transfertnoho tsenoobrazovania, in Bankovskie uslugi (in Russian), 2004, No. 2, p. 5-12.

16. Sokolovskiy S. Metodyka otsinky osnovnykh finansovykh operatsiy komertsiynoho banku za dopomohoyu systemy transfertnoho tsinoutvorennia, in Visnyk Natsionalnoho banku Ukrainy, 2000, No. 8, p. 31-33.

17. Utkin Ye.A. Tseny. Tsenoobrazovanie. Tsenovaya politika: Uchebnik, Moscow, Ekmos, 1997.

18. Shulga N.P. Transfertne tsinoutvorennia yak instrument biudzhetuvannia komertsiynoho banku, in Problemy i perspektyvy rozvytky bankivskoyi systemy Ukrainy, V. 5, Sumy, Mriya LTD, 2002.

19. Ekonomika predpriyatiya, Ed. by O.I. Volkov, Moscow, Infra-M, 1997.

20. Adelberg, A. Resolving conflicts in intracompany transfer pricing, in Accountancy, 1986, November, p. 8689.

21. Charles I. The economics approach to transfer price, in Accountancy, 1985, June, p. 110-112.

22. Charles I. Transfer-price solution where market exists, in Accountancy, 1986, July, p. 96-99.

23. Colin Drury. Management and Cost Accounting, fourth edition, London, International Thomson Business Press, 1996.

24. Drury C., Braund S., Osborne P. and Tayles M. A Survey of Management Accounting Practices in UK Manufacturing Companies, London, ACCA Research Paper, Chartered Association of Certified Accountants, 1993.

25. Laixun Zhao. Decentralization and Transfer Pricing Under Oligopoly, in Southern Economic Journal, 2000, $67(2), p .414-426$.

26. Mostafa A., Sharp J. and Howard K. Transfer pricing - survey using discriminant analysis, in Omega, 1984, $12(5)$, p. 465-474.

27.Roger Y.W. Tang, C.K. Walter, and R.H. Raymond. Transfer Pricing - Japanese vs. American Style, in Management Accounting, 1979, January, p. 12-16. 
28. Tang R. Transfer pricing in the 1990's, in Management Accounting (USA), 1992, February, p. 22-26.

29. The New United Kingdom Transfer Pricing Rules, in The International Tax Journal, 1999, p. 58-69.

30. Watson D.H. and Baumler J.V. Transfer pricing: a behavioural context, in Accounting Review, 1975, 50(3), p. 466-474.

The article was received by the editorial board on 15.03.2006. 
ANNEX 1

\section{Calculation of the Hirschmann-Herfindale index and market power index for the leading banks}

Market power index for the leading banks:

$31.17 \%$

Hirschmann-Herfindale index:

389. 393

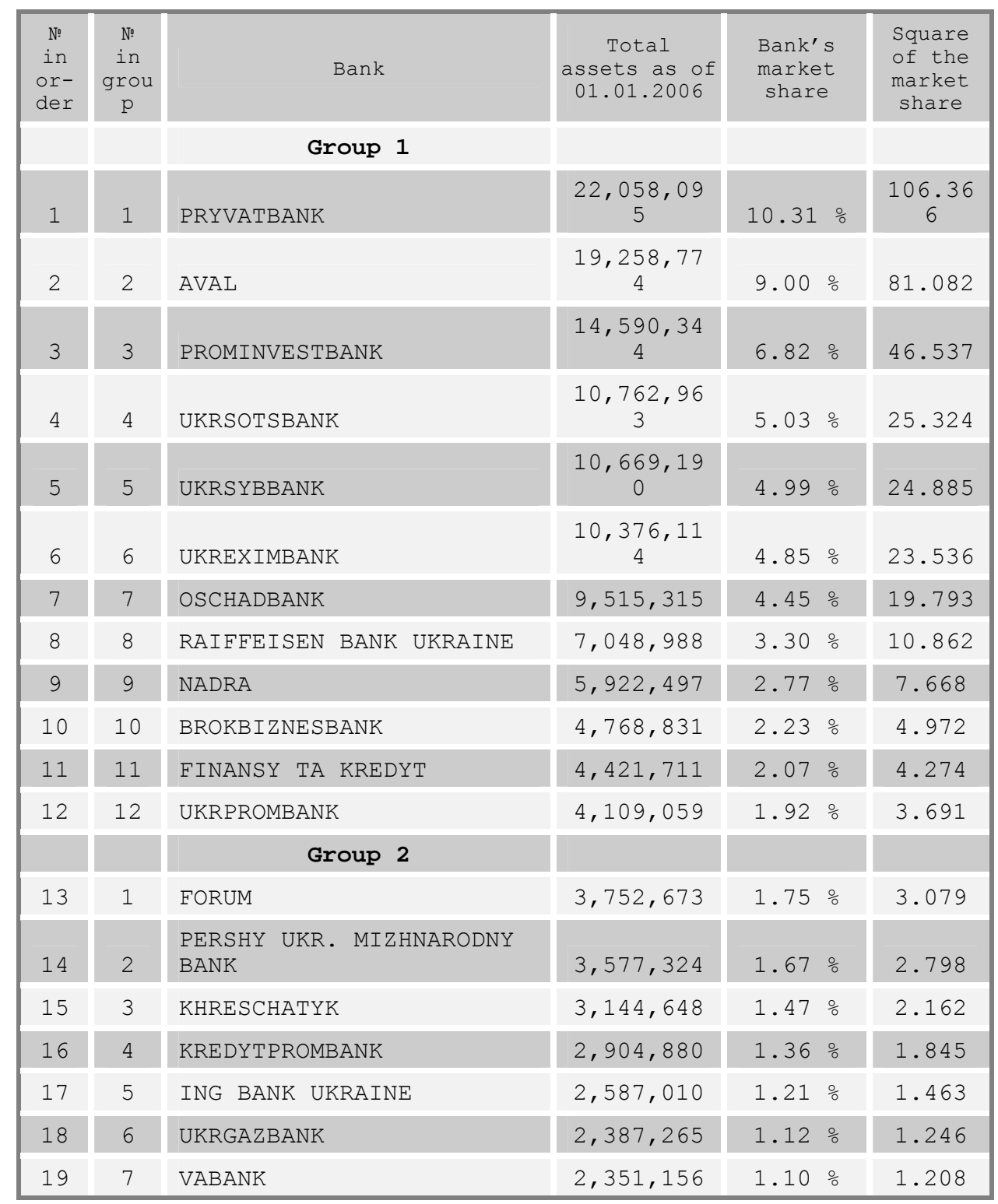




\begin{tabular}{|c|c|c|c|c|c|c|}
\hline $\begin{array}{l}\text { № } \\
\text { in } \\
\text { or- } \\
\text { der }\end{array}$ & $\begin{array}{l}\text { № } \\
\text { in } \\
\text { grou } \\
\text { p }\end{array}$ & Bank & $\begin{array}{c}\text { Total } \\
\text { assets as of } \\
01.01 .2006\end{array}$ & $\begin{array}{l}\text { Bank' }^{\prime} \\
\text { marke } \\
\text { share }\end{array}$ & & $\begin{array}{l}\text { Square } \\
\text { of the } \\
\text { market } \\
\text { share }\end{array}$ \\
\hline 20 & 8 & PIVDENNY & $2,302,891$ & 1.08 & $\%$ & 1.159 \\
\hline 21 & 9 & $\begin{array}{l}\text { INDUSTRIALNO-EXPORT. } \\
\text { BANK }\end{array}$ & $2,215,329$ & 1.04 & $\%$ & 1.073 \\
\hline 22 & 10 & DONGORBANK & $2,141,040$ & 1.00 & $\%$ & 1.002 \\
\hline 23 & 11 & ALFA-BANK & $2,132,548$ & 1.00 & $\%$ & 0.994 \\
\hline 24 & 12 & PRAVEX-BANK & $2,123,520$ & 0.99 & $\%$ & 0.986 \\
\hline 25 & 13 & KREDYT BANK (UKRAINE) & $2,028,417$ & 0.95 & $\%$ & 0.899 \\
\hline 26 & 14 & TAS-KOMERTSBANK & $2,024,159$ & 0.95 & $\%$ & 0.896 \\
\hline \multirow[t]{2}{*}{27} & 15 & MRIYA & $1,927,942$ & 0.90 & $\%$ & 0.813 \\
\hline & & Group 3 & & & & \\
\hline 28 & 1 & RODOVID BANK & $1,829,178$ & 0.86 & $\%$ & 0.731 \\
\hline 29 & 2 & INDUSTRIALBANK & $1,799,289$ & 0.84 & $\%$ & 0.708 \\
\hline 30 & 3 & IMEXBANK & $1,625,807$ & 0.76 & $\%$ & 0.578 \\
\hline 31 & 4 & CITIBANK (UKRAINE) & $1,573,301$ & 0.74 & $\%$ & 0.541 \\
\hline 32 & 5 & KHFB BANK UKRAINE & $1,520,840$ & 0.71 & $\%$ & 0.506 \\
\hline 33 & 6 & EXPRESS-BANK & $1,455,108$ & 0.68 & $\%$ & 0.463 \\
\hline 34 & 7 & KYIV & $1,441,494$ & 0.67 & $\%$ & 0.454 \\
\hline 35 & 8 & TAS-INVESTBANK & $1,237,675$ & 0.58 & $\%$ & 0.335 \\
\hline 36 & 9 & KREDYT-DNIPRO & $1,095,207$ & 0.51 & $\%$ & 0.262 \\
\hline 37 & 10 & PROCREDIT BANK & $1,073,555$ & 0.50 & $\%$ & 0.252 \\
\hline 38 & 11 & MORSKY TRANSPORTNY BANK & $1,051,021$ & 0.49 & $\%$ & 0.241 \\
\hline 39 & 12 & BIG ENERGIA & $1,013,015$ & 0.47 & $\%$ & 0.224 \\
\hline 40 & 13 & KALION BANK UKRAINE & 948,268 & 0.44 & $\%$ & 0.197 \\
\hline 41 & 14 & NRB-UKRA İNA & 902,363 & 0.42 & $\%$ & 0.178 \\
\hline 42 & 15 & MEGABANK & 812,129 & 0.38 & $\%$ & 0.144 \\
\hline 43 & 16 & EXPOBANK & 734,469 & 0.34 & $\%$ & 0.118 \\
\hline 44 & 17 & $\begin{array}{l}\text { UNIVERSALNY BANK ROZVYT. } \\
\text { TA PARTN. }\end{array}$ & 722,879 & 0.34 & $\%$ & 0.114 \\
\hline 45 & 18 & UKRINBANK & 708,722 & 0.33 & $\%$ & 0.110 \\
\hline 46 & 19 & FAKTORIAL-BANK & 690,556 & 0.32 & $\%$ & 0.104 \\
\hline 47 & 20 & DIAMANT & 679,966 & 0.32 & $\%$ & 0.101 \\
\hline
\end{tabular}




\begin{tabular}{|c|c|c|c|c|c|}
\hline $\begin{array}{l}\text { № } \\
\text { in } \\
\text { or- } \\
\text { der }\end{array}$ & $\begin{array}{c}\text { № } \\
\text { in } \\
\text { grou } \\
\text { p }\end{array}$ & Bank & $\begin{array}{c}\text { Total } \\
\text { assets as of } \\
01.01 .2006\end{array}$ & $\begin{array}{c}\text { Bank's } \\
\text { market } \\
\text { share }\end{array}$ & $\begin{array}{l}\text { Square } \\
\text { of the } \\
\text { market } \\
\text { share }\end{array}$ \\
\hline 48 & 21 & ZAKHIDINKOMBANK & 673,496 & $0.31 \%$ & 0.099 \\
\hline 49 & 22 & TAVRYKA & 654,698 & $0.31 \%$ & 0.094 \\
\hline 50 & 23 & KYIVSKA RUS & 626,763 & $0.29 \div$ & 0.086 \\
\hline 51 & 24 & DNISTER & 615,704 & $0.29 \div$ & 0.083 \\
\hline 52 & 25 & AZHIO & 613,719 & $0.29 \div$ & 0.082 \\
\hline 53 & 26 & PERSHY INVESTYTSINY BANK & 587,530 & $0.27 \%$ & 0.075 \\
\hline 54 & 27 & AGROBANK & 572,450 & $0.27 \%$ & 0.072 \\
\hline \multirow[t]{2}{*}{55} & 28 & $\begin{array}{l}\text { BANK PETROCOMMERCE- } \\
\text { UKRAINE }\end{array}$ & 551,847 & $0.26 \div$ & 0.067 \\
\hline & & Group 4 & & & \\
\hline 56 & 1 & FINANSOVA INITSIATYVA & 743,694 & $0.35 \div$ & 0.121 \\
\hline 57 & 2 & AKTYV BANK & 605,984 & $0.28 \%$ & 0.080 \\
\hline 58 & 3 & VNESHTORGBANK & 562,886 & $0.26 \%$ & 0.069 \\
\hline 59 & 4 & ELEKTRON BANK & 514,188 & $0.24 \%$ & 0.058 \\
\hline 60 & 5 & BAZYS & 490,542 & $0.23 \div$ & 0.053 \\
\hline 61 & 6 & TRANSBANK & 473,802 & $0.22 \div$ & 0.049 \\
\hline 62 & 7 & ARKADA & 473,210 & $0.22 \%$ & 0.049 \\
\hline 63 & 8 & $\begin{array}{l}\text { MIZHNARODNY KOMERTSIYNY } \\
\text { BANK }\end{array}$ & 466,807 & $0.22 \div$ & 0.048 \\
\hline 64 & 9 & NATSIONALNI INVESTYTSIYI & 461,705 & $0.22 \div$ & 0.047 \\
\hline 65 & 10 & $\begin{array}{l}\text { UKRAINSKY PROFESIYNY } \\
\text { BANK }\end{array}$ & 443,307 & $0.21 \%$ & 0.043 \\
\hline 66 & 11 & ZOLOTI VOROTA & 441,366 & $0.21 \div$ & 0.043 \\
\hline 67 & 12 & POLTAVA BANK & 439,258 & $0.21 \div$ & 0.042 \\
\hline 68 & 13 & AVTOZAZBANK & 436,812 & $0.20 \%$ & 0.042 \\
\hline 69 & 14 & ENERGOBANK & 432,302 & $0.20 \%$ & 0.041 \\
\hline 70 & 15 & UKRGAZPROMBANK & 417,351 & $0.20 \div$ & 0.038 \\
\hline 71 & 16 & FINANSOVY SOYUZ BANK & 408,110 & $0.19 \%$ & 0.036 \\
\hline 72 & 17 & YEVROPEISKY & 406,406 & $0.19 \%$ & 0.036 \\
\hline 73 & 18 & UKRAINSKY FINANSOVY SVIT & 395,660 & $0.18 \div$ & 0.034 \\
\hline 74 & 19 & $\begin{array}{l}\text { BANK REGIONALNOGO ROZ- } \\
\text { VYTKU }\end{array}$ & 390,343 & $0.18 \div$ & 0.033 \\
\hline
\end{tabular}




\begin{tabular}{|c|c|c|c|c|c|}
\hline $\begin{array}{l}\text { № } \\
\text { in } \\
\text { or- } \\
\text { der }\end{array}$ & $\begin{array}{c}\text { № } \\
\text { in } \\
\text { grou } \\
\text { p }\end{array}$ & Bank & $\begin{array}{c}\text { Total } \\
\text { assets as of } \\
01.01 .2006\end{array}$ & $\begin{array}{l}\text { Bank's } \\
\text { market } \\
\text { share }\end{array}$ & $\begin{array}{l}\text { Square } \\
\text { of the } \\
\text { market } \\
\text { share }\end{array}$ \\
\hline 75 & 20 & MISTO-BANK & 389,113 & $0.18 \%$ & 0.033 \\
\hline 76 & 21 & UNIVERSALNY & 385,527 & $0.18 \%$ & 0.032 \\
\hline 77 & 22 & NOVY & 379,050 & $0.18 \%$ & 0.031 \\
\hline 78 & 23 & INPROMBANK & 376,342 & $0.18 \%$ & 0.031 \\
\hline 79 & 24 & FORTUNA BANK & 352,307 & $0.16 \%$ & 0.027 \\
\hline 80 & 25 & MERKURI & 345,958 & $0.16 \%$ & 0.026 \\
\hline 81 & 26 & NATSIONALNY KREDYT & 335,283 & $0.16 \%$ & 0.025 \\
\hline 82 & 27 & ARTEM BANK & 317,829 & $0.15 \%$ & 0.022 \\
\hline 83 & 28 & KAPITAL & 314,429 & $0.15 \%$ & 0.022 \\
\hline 84 & 29 & UKRKOMUNBANK & 304,574 & $0.14 \%$ & 0.020 \\
\hline 85 & 30 & SKHIDNOYEVROPESKY BANK & 303,227 & $0.14 \%$ & 0.020 \\
\hline 86 & 31 & UKRAINSKY BIZNES BANK & 297,655 & $0.14 \div$ & 0.019 \\
\hline 87 & 32 & LEGBANK & 296,484 & $0.14 \%$ & 0.019 \\
\hline 88 & 33 & KLIRYNGOVY DIM & 295,441 & $0.14 \%$ & 0.019 \\
\hline 89 & 34 & KAMBIO & 294,164 & $0.14 \%$ & 0.019 \\
\hline 90 & 35 & METALURG & 287,296 & $0.13 \%$ & 0.018 \\
\hline 91 & 36 & $\begin{array}{l}\text { YEVROPEISKYI BANK ROZ- } \\
\text { VYT. TA ZAOSCH. }\end{array}$ & 286,672 & $0.13 \%$ & 0.018 \\
\hline 92 & 37 & UKRAINSKY KREDYTNY BANK & 285,661 & $0.13 \%$ & 0.018 \\
\hline 93 & 38 & AGRARNY KOMERTSIYNY BANK & 284,598 & $0.13 \%$ & 0.018 \\
\hline 94 & 39 & PROMEKONOMBANK & 267,366 & $0.13 \%$ & 0.016 \\
\hline 95 & 40 & DEMARK & 259,148 & $0.12 \%$ & 0.015 \\
\hline 96 & 41 & PRYVATINVEST & 240,051 & $0.11 \%$ & 0.013 \\
\hline 97 & 42 & INTEGRAL & 237,856 & $0.11 \%$ & 0.012 \\
\hline 98 & 43 & SYNTEZ & 235,211 & $0.11 \%$ & 0.012 \\
\hline 99 & 44 & INTERBANK & 229,845 & $0.11 \%$ & 0.012 \\
\hline 100 & 45 & INTERKONTYNENTBANK & 229,661 & $0.11 \%$ & 0.012 \\
\hline 101 & 46 & PIVDENKOMBANK & 226,652 & $0.11 \%$ & 0.011 \\
\hline 102 & 47 & AVTOKRAZBANK & 225,838 & $0.11 \%$ & 0.011 \\
\hline 103 & 48 & $\begin{array}{l}\text { YEVROPEISKY BANK } \\
\text { RATSION. FINANS. }\end{array}$ & 217,436 & $0.10 \%$ & 0.010 \\
\hline
\end{tabular}




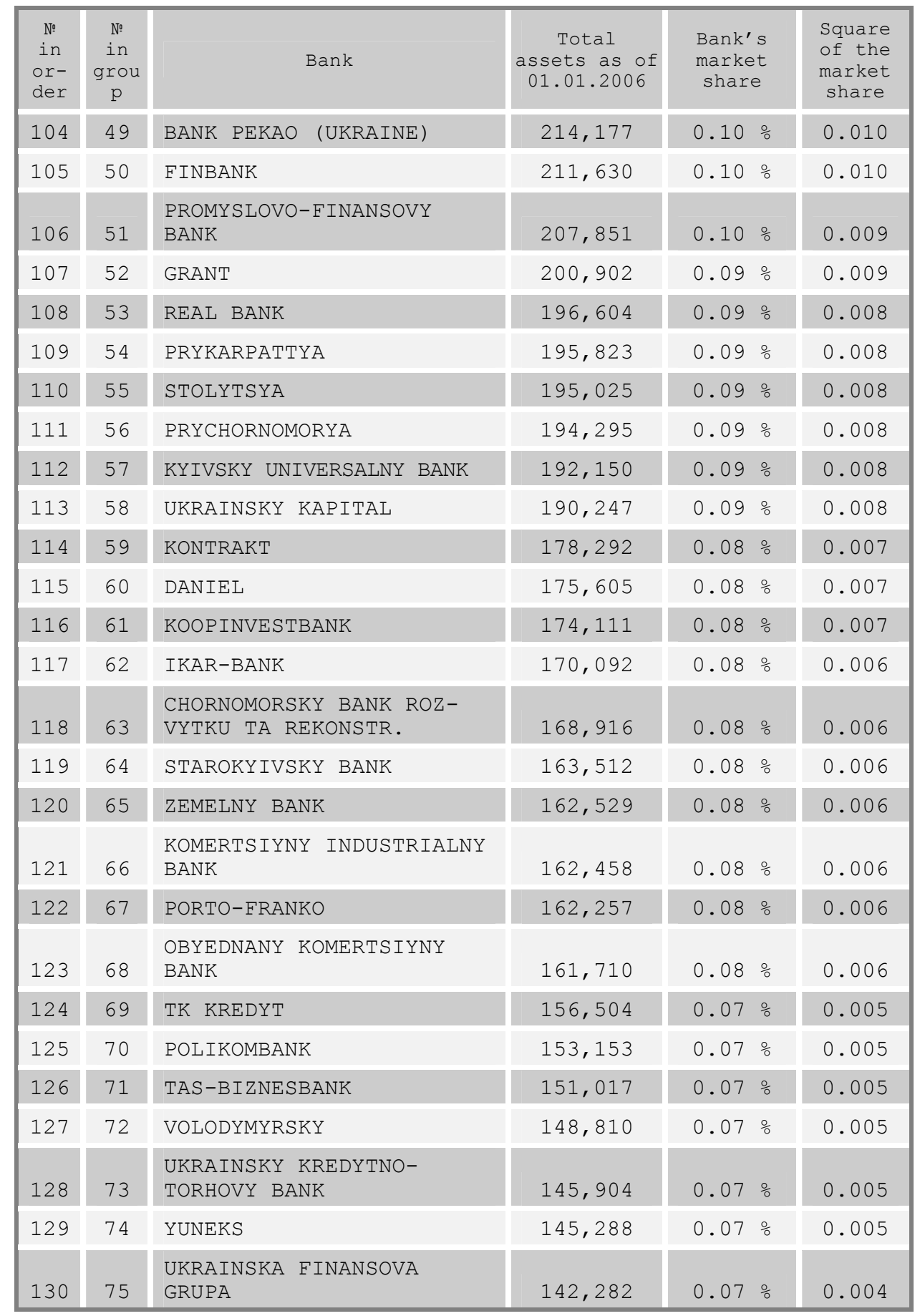




\begin{tabular}{|c|c|c|c|c|c|}
\hline $\begin{array}{l}\text { № } \\
\text { in } \\
\text { or- } \\
\text { der }\end{array}$ & $\begin{array}{l}\text { № } \\
\text { in } \\
\text { grou } \\
\text { p }\end{array}$ & Bank & $\begin{array}{c}\text { Total } \\
\text { assets as of } \\
01.01 .2006\end{array}$ & $\begin{array}{l}\text { Bank's } \\
\text { market } \\
\text { share }\end{array}$ & $\begin{array}{l}\text { Square } \\
\text { of the } \\
\text { market } \\
\text { share }\end{array}$ \\
\hline 131 & 76 & SOTSKOMBANK & 131,091 & $0.06 \div$ & 0.004 \\
\hline 132 & 77 & INVESTBANK & 125,100 & $0.06 \div$ & 0.003 \\
\hline 133 & 78 & FAMI LNY & 122,767 & $0.06 \%$ & 0.003 \\
\hline 134 & 79 & ARMA & 121,561 & $0.06 \div$ & 0.003 \\
\hline 135 & 80 & ODESA-BANK & 113,451 & $0.05 \div$ & 0.003 \\
\hline 136 & 81 & UKOOPSPILKA & 112,412 & $0.05 \%$ & 0.003 \\
\hline 137 & 82 & REGION BANK & 111,197 & $0.05 \div$ & 0.003 \\
\hline 138 & 83 & DIALOGBANK & 106,391 & $0.05 \%$ & 0.002 \\
\hline 139 & 84 & TRAST-KAPITAL & 103,528 & $0.05 \%$ & 0.002 \\
\hline 140 & 85 & TMM-BANK & 102,511 & $0.05 \%$ & 0.002 \\
\hline 141 & 86 & LVIV & 101,521 & $0.05 \div$ & 0.002 \\
\hline 142 & 87 & MORSKY & 101,272 & $0.05 \%$ & 0.002 \\
\hline 143 & 88 & SLAVUTYCH & 99,394 & $0.05 \%$ & 0.002 \\
\hline 144 & 89 & INVEST-KRYVBAS BANK & 96,702 & $0.05 \div$ & 0.002 \\
\hline 145 & 90 & OLIMPIYSKA UKRAINA & 90,850 & $0.04 \div$ & 0.002 \\
\hline 146 & 91 & $\begin{array}{l}\text { SKHIDNO-PROMYSL. } \\
\text { KOMERTS. BANK }\end{array}$ & 90,116 & $0.04 \%$ & 0.002 \\
\hline 147 & 92 & BANK «PERSPEKTYVA» & 88,614 & $0.04 \%$ & 0.002 \\
\hline 148 & 93 & $\begin{array}{l}\text { MIZHNARODNY IPOTECHNY } \\
\text { BANK }\end{array}$ & 88,008 & $0.04 \%$ & 0.002 \\
\hline 149 & 94 & ZEMELNY KAPITAL & 78,789 & $0.04 \%$ & 0.001 \\
\hline 150 & 95 & PRAIM-BANK & 78,112 & $0.04 \%$ & 0.001 \\
\hline 151 & 96 & FINEXBANK & 69,438 & $0.03 \%$ & 0.001 \\
\hline 152 & 97 & RADABANK & 67,019 & $0.03 \div$ & 0.001 \\
\hline 153 & 98 & VELES & 63,334 & $0.03 \%$ & 0.001 \\
\hline 154 & 99 & FINROSTBANK & 61,868 & $0.03 \div$ & 0.001 \\
\hline 155 & 100 & GARANT & 59,748 & $0.03 \%$ & 0.001 \\
\hline 156 & 101 & $\begin{array}{l}\text { UKRAINSKY BUDIVELNO- } \\
\text { INVEST.BANK }\end{array}$ & 55,510 & $0.03 \%$ & 0.001 \\
\hline 157 & 102 & ALYANS & 54,527 & $0.03 \div$ & 0.001 \\
\hline 158 & 103 & FERMERSKY ZEMELNY BANK & 54,068 & $0.03 \div$ & 0.001 \\
\hline 159 & 104 & UKRAINSKY BANK REK- & 45,319 & $0.02 \div$ & 0.000 \\
\hline
\end{tabular}




\begin{tabular}{|c|c|l|c|c|c|}
\hline $\begin{array}{c}\text { No } \\
\text { in } \\
\text { or- } \\
\text { der }\end{array}$ & $\begin{array}{c}\text { No } \\
\text { in } \\
\mathrm{p}\end{array}$
\end{tabular}

